\title{
Seed removal of Dipteryx alata Vog. (Leguminosae: Faboidae) in the edge and interior of Cerrado
}

\author{
J. Ragusa-Netto ${ }^{a *}$ \\ aDepartamento de Ciências Naturais, Universidade Federal de Mato Grosso do Sul - UFMS, Campus Três Lagoas, \\ Avenida Ranulpho Marques Leal, 3484, CP 210, CEP 79610-100, Três Lagoas, MS, Brazil \\ *e-mail: jragusanetto@yahoo.com
}

Received: December 10, 2015 - Accepted: June 1, 2016 - Distributed: November 31, 2017

(With 2 figures)

\begin{abstract}
Post-dispersal seed agents of mortality include pathogens, invertebrates, and vertebrates, which may shape tropical tree populations and communities. In this study I experimentally evaluated Dipteryx alata endocarp removal both in the interior and edge of Cerrado vegetation. Specifically, I simulated primary dispersion of endocarps by bats and evaluated secondary removal intensity according to habitat, season, and endocarp number. This study was developed in the Pombo Natural Municipal Park, a large Cerrado remnant with an area of 9,000 ha, located in the Western Brazil. In each of the two habitat types, I set down 45 points in which $D$. alata piles of $1,3,7,15$, and 40 endocarps were positioned. On average, endocarp removal in the interior was higher than in the edge, so that the intensity of removal varied from positive density-dependent (interior: rains), to negative density-dependent (edge: both seasons). Also, at both habitat types and seasons non removed endocarps were intensely attacked by fungus. Indeed, seed mortality by fungus infestation was positive density-dependent. The results indicate high propensity of endocarps to escape from removal in the edge, in principle, a defaunated area. As Dipteryx species strongly rely on caviomorph rodents for their dispersal, the scarcity of these vectors might reduce recruitment chances of $D$. alata in remnants of Cerrado. This imply in future changes in the vegetation structure from the edge to the interior towards low tree diversity.
\end{abstract}

Keywords: seed predation, seed dispersal, plant-animal interaction, density-dependence, Cerrado fragment, vegetation edge.

\section{Remoção de sementes de Dipteryx alata Vog. (Leguminosae: Faboidae) na borda e interior do Cerrado}

\begin{abstract}
Resumo
A mortalidade pós-dispersão de sementes é causada por agentes como patógenos, invertebrados e vertebrados, os quais influenciam a dinâmica de populações e comunidades arbóreas. Nesse estudo, avaliei experimentalmente intensidade de remoção, por roedores, de endocarpos de Dipteryx alata na borda e interior da vegetação do Cerrado. Simulando a dispersão primária por morcegos, posicionei pilhas com diferentes números de endocarpos nos dois hábitats do cerrado e avaliei a remoção secundária, tanto na estação seca quanto na chuvosa. Os experimentos foram desenvolvidos no Parque Natural Municipal do Pombo, um grande remanescente com 9000 ha (Três Lagoas, MS, Brasil). Em cada um dos habitat defini 45 pontos nos quais pilhas com 1, 3, 7, 15 e 40 endocarpos foram posicionadas. A remoção de endocarpos foi significativamente maior no interior em relação à borda, tal que a intensidade de remoção variou de positivamente dependente da densidade (interior: chuvas), a negativamente dependente da densidade (borda: ambas as estações). Além disso, tanto na borda, quanto interior, bem como nas duas estações os endocarpos não removidos foram intensamente infestados por fungos. Consequentemente, a mortalidade causada por esses patógenos foi densidade dependente. Os resultados sugerem que os endocarpos de $D$. alata teriam maiores chances de escapar à remoção na borda, em princípio, depauperada em termos de roedores dispersores. A escassez desses vetores reduziria as chances de recrutamento de $D$. alata, favorecendo mudanças futuras na estrutura da vegetação, a partir da borda, em termos de menor diversidade arbórea.
\end{abstract}

Palavras-chave: predação de sementes, dispersão de sementes, interação planta-animal, densidade-dependente, remanescente de cerrado, borda de vegetação. 


\section{Introduction}

Seeds and seedlings represent the most vulnerable stage in a tree's development to biotic and abiotic factors of mortality, which have importance in determining plant reproductive success (Bagchi et al., 2010). Biotic post-dispersal agents of mortality include vertebrates, invertebrates, and pathogens, all of which can significantly alter the structure and dynamics of tree populations and communities (Harms et al., 2000; Terborgh, 2012). The Janzen-Connell model (Janzen, 1970; Connell, 1971) predicts that seed predators will exert greater predation pressures at places in which dispersed seeds are densest or closest to reproductive conspecifics. Indeed, the so called distance- or density dependent mortality is thought to occur most strongly during early stages of plant development, when individuals are most abundant and vulnerable to enemies (Howe and Smallwood, 1982; Bagchi et al., 2010; Terborgh, 2012). As a result, density-dependent mortality during recruitment leads to a decreased probability that a species will replace itself at a site, which may promotes maintenance of diversity (Janzen, 1970; Forget et al., 2000; Terborgh, 2012).

Seed predation is heavily influenced by life history characteristics of tree species (Terborgh, 2012). In this respect, species with vertebrate dispersed seeds can have similar seed shadows but drastically different seed predation rates (Silman et al., 2003). The dual role of vertebrates suggests that changes in vertebrate communities can alter tree community composition (Asquith et al., 1997). Then, the impact of density-dependence may differ conform habitat type (Givnish, 1999), as well as tree community (Barot and Gignoux, 2004). As example, seed survival may be reduced in gaps relative to the understory of pristine forest, but seedling survival and growth may be enhanced due to increased light levels. Canopy gaps, although unpredictable in space and time, are assumed as areas for colonization and enhanced recruitment (sensu Howe and Smallwood, 1982). These sites may buffer the detrimental effects of natural enemies, especially among seedlings (Wenny, 2000). In spite of potential seed success in this altered area, in the case of forest fragmentation the creation of edge habitats is responsible for more severe modifications in community dynamics (Murcia, 1995; Saunders et al., 1991).

Plant recruitment along edges is favored for early successional species but is limited for core forest ones (Williams-Linera, 1990; Fox et al., 1997). Consequently, seed resource availability along edges is dominated by small seeds, often produced in large quantities by pioneering tree species (Hammond and Brown, 1995; Melo et al., 2006). Such seeds are more attractive to small than to large scatterhoarding rodents (Adler, 1998). Moreover, the density and activity of forest animals in edge habitats can also be altered as a consequence of their specific responses to habitat changes, varying from edge avoidance to edge preference (Bowers and Dooley Junior, 1993; Goosem, 2000). Some studies have shown that the abundance of rodents increase in small fragments and at forest edges in comparison to large fragments and the forest interior (Asquith et al., 1997; Donoso et al., 2004), whereas others found that abundance of rodents decrease due to fragmentation (Hanson et al., 2006). These changes in rodent community may negatively affect plant-rodent interactions in edge habitats (Holl and Lulow, 1997). According to the role of rodents (predators/dispersers), such variations in rodent abundance can influence the life cycle of tree species, especially effective seed dispersal and seedling establishment (Cordeiro and Howe, 2003). In fact, habitat fragmentation can indirectly influence plant community patterns due modifications in both the distribution and abundance of rodents and, in turn, seed predation/dispersal by these mammals (Terborgh and Wright, 1994; Asquith et al., 1997).

Bats are often common in anthropized landscapes of tropical areas (Aguirre et al., 2003). This tolerance to habitat perturbation might be explained by their ability to cross habitat mosaics to reach food resources that are patchy in space and time (Montiel et al., 2006). Frugivorous bats often perform the dispersal of large seeded species, which they cannot ingest, by depositing seeds under feeding roosts after pulp consumption (Melo et al., 2009). In the tropical vegetation frugivorous bats often use feeding roost either in the interior or edge of Neotropical forest remnants (Arteaga et al., 2006). This also occurs in the fragmented Cerrado (Neotropical savanna; Ribeiro and Walter, 1998), so that under feeding roosts a gradient of seed densities may be generated (Ragusa-Netto and Santos, 2015). Therefore, one may expect differences in the chances of seed survival according to seed densities (Harms et al., 2000; Terborgh, 2012). Also, the edge exhibits both physical and biotic differences from forest interior, and these two habitats may differ in quality for seed establishment, a process dependent on where seeds are deposited because microhabitat characteristics associated with deposition site will ultimately define the probability of seed survival (Fleury and Galetti, 2006).

Dypterix alata Vog. is a common and prominent tree species from Brazilian Cerrado, beside dry forests (Lorenzi, 1994). From the early dry to the early rainy season fruiting trees present single-seeded drupes which are exploited by mammals such as bats (Lorenzi, 1994). After they ingest the pulp, bats may deposit up to 40 thick wood D. alata endocarps under feeding roosts either in the interior or edges of Cerrado (J. Ragusa-Netto, pers. obs., Romo et al., 2004). Secondary removal is common in Dipteryx spp (Romo et al., 2004), and piles of D. alata endocarps might suffer different levels of removal according to their density, habitat (interior vs edge), and season, as result of general seed fall (Schupp, 1992). In fact, dispersion of vertebrate-dispersed tree species, then, can be viewed in terms of the balance between dispersal processes that aggregate seeds and post-dispersal processes that alter the initial offspring dispersion pattern through non-random survival (Schupp and Fuentes, 1995). In this study, by the simulation of primary endocarp dispersal by bats, 
I experimentally evaluated $D$. alata secondary endocarp removal both in the interior and edge of Cerrado vegetation. Taking into account that understanding the effects of habitat fragmentation on seed removal (dispersal/predation) has important management and conservation implications, this is valid for D. alata which is economically important (timber and nutritive seeds, e. g. Lorenzi, 1994), and is declining together with the Cerrado and dry forest areas (Carvalho et al., 2009).

\section{Methods}

\subsection{Study area}

This study was carried out in the Pombo Natural Municipal Park (hereafter PNMP), a large Cerrado remnant with an area of 9,000 ha, located in the Western Brazil (municipality of Três Lagoas, eastern side of Mato Grosso do Sul State, $20^{\circ} 24^{\prime}-20^{\circ} 18^{\prime} \mathrm{S}$ and $52^{\circ} 41^{\prime}-52^{\circ} 38^{\prime} \mathrm{W}$, altitude $350-480 \mathrm{~m}$ ). The climate is marked seasonal with a wet (October-March), and a pronounced dry season (April-September). Annual rainfall is approximately $1,400 \mathrm{~mm}(70 \%$ in the wet season), and mean annual temperature lies around $24.6{ }^{\circ} \mathrm{C}$. The vegetation in the area is a mosaic of dense gallery forest (Pombo river, and streams in the margin of PNMP), palm stands (Mauritia flexuosa L.f.), and the dominant Cerrado, which exhibit a gradient including from open fields to dense wood vegetation. However, much of the Cerrado is comprised by savanna-like and dense types of Cerrado, in which trees exhibit from 2 to $10 \mathrm{~m}$ in height. During the dry season tree species shed their leaves, mainly in the late dry season (August and September). Data collection was developed in the northern part of PNMP (20 $19^{\prime}$ 'S and 52 $36^{\prime} \mathrm{W}$, altitude $446 \mathrm{~m}$ ), the only site where pastures occur in the edge of dense Cerrado vegetation. Characteristic trees include Pouteria torta (Mart.) Radlk., Qualea grandiflora Mart., Q. parviflora Mart., Hymenaea stigonocarpa Mart. ex Hayne, Caryocar brasiliense Cambess., Copaifera langsdorffii Desf., Annona crassiflora Mart., Anadenanthera falcata (Benth.) Speg., and Curatella americana L.

\subsection{Experimental design}

The experiment was designed to evaluate, both in the edge and interior of Cerrado, removal intensity according to D. alata endocarp number and year period, namely the late dry and the early wet season. In these periods those endocarps were often deposited by bats under feeding roosts (Ragusa-Netto and Santos, 2015), while general fruiting pattern highly vary in the dense Cerrado (Ragusa-Netto, 2006). In each habitat type one 1500-m transect was delimited: the edge transect, at 5-10 m from the Cerrado boundary, and the interior transect, $400 \mathrm{~m}$ away from the edge. In each transect, I set down 45 points (30 $\mathrm{m}$ apart from each other), in which, by simulating primary dispersal by bats I positioned $D$. alata endocarp piles. At every point an area of approximately $50 \mathrm{~cm}^{2}$ was cleared of leaf litter for the placement of endocarps. For each trial, both in the edge and interior I placed on the soil $1,3,7,15$, and 40 endocarps $(n=9$ for each density, hereafter referred to as depots). The disposition of 45 depots according to endocarp number was rotated. Each depot was assumed as a replicate for analyses, as $30 \mathrm{~m}$ assure independence between samples. In fact, earlier studies have demonstrated the influence of microhabitat on rodent foraging activity, and have further revealed that $20 \mathrm{~m}$ distances between seed sets provide independent observations for the assessment of seed removal (Chauvet and Forget, 2005). Prior to the definition of those transects, both habitats were checked for the presence of fruiting D. alata, to avoid uncontrolled fruits accumulated in the vicinity of experimental $D$. alata endocarp depots. Then, care was taken to design both transects at least $50 \mathrm{~m}$ apart from any $D$. alata tree. Depots with endocarps were set out 01 August, and 01 November 2014. Endocarps were counted and removed from depots after 30 days, between 10:30 and 15:30 h. Any endocarp that was preyed upon in situ (confirmed by the presence of a hole with rodent teeth marks), or removed was considered, in principle, to have been subject to predation, while those remaining in the depots were considered intact; however, because I do not know the fate of each endocarp after they were removed from depots, rates of endocarp removal will be used instead of endocarp predation when discussing the results. Non removed endocarps were placed on drying paper and stored in properly labeled plastic bags. Once back in the laboratory, endocarps were opened for an examination of the seed condition and were classed in three categories: a) intact, for no sign of mortality agent; b) preyed upon by insects, when endocarps presented a larva or an adult inside them, or presented entry or exit holes; and c) infested by fungus, seeds were found decaying inside endocarps, and with the presence of hyphae. For each trial I collected $>400$ D. alata fruits from over 10 trees located in pastures in the rural zone of Três Lagoas City. I peeled away the pulp to expose the hard endocarp, and discarded all seeds with insect holes or other damage, such as fungus infection. I tested for endocarp viability by placing them in water, and excluding the floating unsound ones, which were also likely to be parasitized or aborted. From the screened, pulp-free endocarps, I randomly selected 50 and measured (length and diameter), and weighed them to assess mean size and weight.

\subsection{Analyzes}

Taking into account the potential intra-seasonal changes in general food resources availability and consequent chance of seed consumption, I tested D. alata endocarp removal in two periods of the year (see above). Also, as in principle predators should concentrate their activities in sites where foraging success is likely to be maximum (Schupp, 1988), foraging rodents, for example, might be differently attracted to depots according to endocarp number. In this respect, firstly I analyzed the relationship between initial number of endocarps, and the chance of removal (at least one endocarp) across seasons and habitat type, through Chi-square contingency analysis. To assess 
endocarp removal intensity caused by the initial number of endocarps per depot, I assessed the relationship $\left(I=\mathrm{aR}^{\mathrm{b}}\right)$ between the initial number (I) and the number of removed endocarps (R). Then, I analyzed the initial-removed relationship by linear regression of $\log$ transformed values of $\mathrm{I}+1$ and $\mathrm{R}+1$ (power law equation), to normalize residuals. Indeed, with: $\log (\mathrm{y}+1)=\mathrm{a}+b \log (\mathrm{x}+1)$, I assessed density-dependent effect, where $\mathrm{x}$ is the initial number of endocarps at a given depot and $y$ is the respective number of endocarps removed at the end of the experiment; $b$ is the slope representing the rate in which the number of endocarps removed increases in relation to the initial number of endocarps. The constant $b$ may be equal, minor or higher than 1 . Higher values imply in positive density-dependence, while $b=1$, independence. Values of less than 1 imply in negative density-dependence because per endocarp probability of removal is inversely related to endocarp density. To improve the evaluation on the occurrence of density-dependence, the number of endocarps removed according to observed $b$ values were confronted (Wilcoxon matched pairs test) with the predicted number if $b=1$ (Harms et al., 2000). I also tested the relationship between the number of non removed endocarps at every depot and states of seed condition by regression analysis of $\log$ transformed values. Due to the potential temporal (the wet and the dry season), and spatial (the edge and the interior) variations in the intensity of endocarp removal, I compared the slops of log-log regressions by ANCOVA.

Finally, I compared mean proportions of endocarp removal at the end of the experiment (day 30) with a two-way non-parametric analysis of variance (NPANOVA, Anderson, 2001). Comparisons were performed for both seasons. The first fixed factor had five levels: initial number of endocarps $(1,3,7,15$, and 40 endocarps), and the second fixed factor had two levels: the habitat types (see above). Square-root- proportions of endocarps removed data were arc-sine transformed to reduce heteroscedasticity.

\section{Results}

Mature fruits of $D$. alata had a discoid shape including an ellipsoid one seeded endocarp. Endocarp length ranged from 36.6 to $53.1 \mathrm{~mm}$ (average $[ \pm \mathrm{sd}]: 46.1 \pm 3.5 \mathrm{~mm}$ ); the diameter from 28.3 to $39.8 \mathrm{~mm}(33.6 \pm 2.5 \mathrm{~mm})$, and the thickness from 16.1 to $25.5 \mathrm{~mm}(19.6 \pm 2.0 \mathrm{~mm})$. The weight ranged from 8.6 to $18.6 \mathrm{~g}(13.3 \pm 2.3 \mathrm{~g} ; \mathrm{n}=50)$.

During the dry season 37 depots lost at least one endocarp in the edge, while this occurred with 45 in the interior. Similarly, during the wet season 33 depots in the edge and 44 in the interior lost endocarps. Then, regardless of season, habitat, and initial number, endocarps were removed in most depots, so that no significant association emerged between these variables and the chance of removal of at least one endocarp (Chi-square contingency analysis, $\chi^{2}=1.938$, $\mathrm{df}=12, \mathrm{p}=0.999)$. On the other hand, the intensity of endocarp removal highly varies across seasons and habitat types. In the edge during the dry season I documented the lowest slope value, namely $b=0.69$. During rains slope was also low in the edge $(b=0.87$, Figure 1$)$. I recorded the highest $b$ value during rains in the interior $(b=1.04)$, which was also high in the dry season, when all endocarps were removed ( $b=1$, Figure 1$)$. These slope values were significantly different (ANCOVA, $\mathrm{F}=3.22, \mathrm{p}=0.024$ ). During both the dry and wet seasons, the observed slopes of the log-log regression between the initial-removed number of endocarps were significantly different from $b=0\left(\mathrm{t}=1,010, \mathrm{r}^{2}=1.0, \mathrm{p}<0.0001\right.$ [interior: dry season]; $\mathrm{t}=6.063, \mathrm{r}^{2}=0.461, \mathrm{p}=0.0001$ [edge: dry season]; $\mathrm{t}=29.150$, $\mathrm{r}^{2}=0.952, \mathrm{p}<0.0001$ [interior: wet season]; $\mathrm{t}=6.844$, $\mathrm{r}^{2}=0.521, \mathrm{p}=0.0001$ [edge: wet season]). Also, in the interior during rains the observed endocarp removal was higher than to the expected if $b=1(\mathrm{z}=2.81, \mathrm{p}=0.002)$, and equal to $b=1$ in the dry season. However, in the edge the observed endocarp removal was significantly smaller than the expected if $b=1$ (dry season: $\mathrm{z}=3.83, \mathrm{p}<0.0001$; wet season: $\mathrm{z}=4.29, \mathrm{p}<0.0001)$. Hence, regardless of season, in the edge, the intensity of endocarp removal decreased according to endocarp number, while in the interior it was proportional during the dry, and increased during the wet season. In the rains high proportions of non removed endocarps were attacked by fungus either in the interior $(58.8 \%)$, or the edge $(79.8 \%)$. In the dry season mortality due fungus corresponded to $74.2 \%$ of endocarps in the edge. The number of non removed endocarps and the number of endocarps attacked by fungus were high correlated $\left(\mathrm{r}^{2}=0.56, \mathrm{p}=0.03\right.$ [interior: wet season]; $r^{2}=0.84, p=0.0001$ [edge: wet season]; and $r^{2}=0.85$, $\mathrm{p}=0.0001$ [edge: dry season]). Mortality rate caused by fungus increased with the number of non removed endocarps in both habitats and seasons $(b=1.13$ [interior: wet season], $b=1.25$ [edge: wet season], and $b=1.26$, [edge: dry season]).

In the dry season, $57.8 \%$ of depots in the edge $(n=45)$ lost all endocarps, while $53.0 \%(n=594)$ of endocarps disappeared from this site. Conversely, in the interior $100 \%$ of endocarps disappeared from depots. Besides that, in the edge depots of 40 , on average, lost minor mean proportions of endocarps (average \pm se, $39 \pm 11 \%$ ), while those ones of 15 , lost the highest proportion $(81 \pm 13 \%$, Table 1). In the wet season, most depots in the interior lost all endocarps $(76 \%, \mathrm{n}=45)$, while this occurred with $40 \%$ of depots in the edge. Moreover, $67.7 \%$ of endocarps were removed from the edge, while $97.1 \%$ disappeared from the interior. Depots of 3 suffered minor mean proportion of removal both in the edge (average \pm se, $37 \pm 16 \%$ ), and interior $(85 \pm 8 \%)$. On the other hand, maximum removal occurred in depots of 7 in the edge $(73 \pm 16 \%)$, and in those ones of 40 in the interior (100\%, Table 1). Indeed, mean proportion of removal were smaller in the edge than in the interior in both seasons (Two-way NPANOVA, the dry season: $F=34.63, p=0.0001$; the wet season: $\mathrm{F}=16.44, \mathrm{p}=0.0001$; Figure 2, Table 1). In spite of variations in endocarp removal according to initial number of endocarps, this factor exhibited no significant effect (the dry season: $F=1.09, p=0.37$; the wet season: $\mathrm{F}=1.29, \mathrm{p}=0.28$, Figure 2). Also, there was 
no significant interaction between the two main factors (habitat type and initial number of endocarps per depot), on mean proportion of endocarp removal (the dry season: $\mathrm{F}=1.09, \mathrm{p}=0.36$; the wet season: $\mathrm{F}=0.55, \mathrm{p}=0.70$ ).

In depots of 40, either in the interior or in the edge, some depredated endocarps were left at the site where they were initially placed. These endocarps had large lateral holes with evident rodent teeth marks, presumably caused by Pacas (Cuniculus paca [Linnaeus, 1766]). In the edge, during the dry season, two depots had each one only one depredated endocarp (mean \pm se: $0.2 \pm 0.1, \mathrm{n}=9$ depots of 40), while in the wet season four depots had a total of

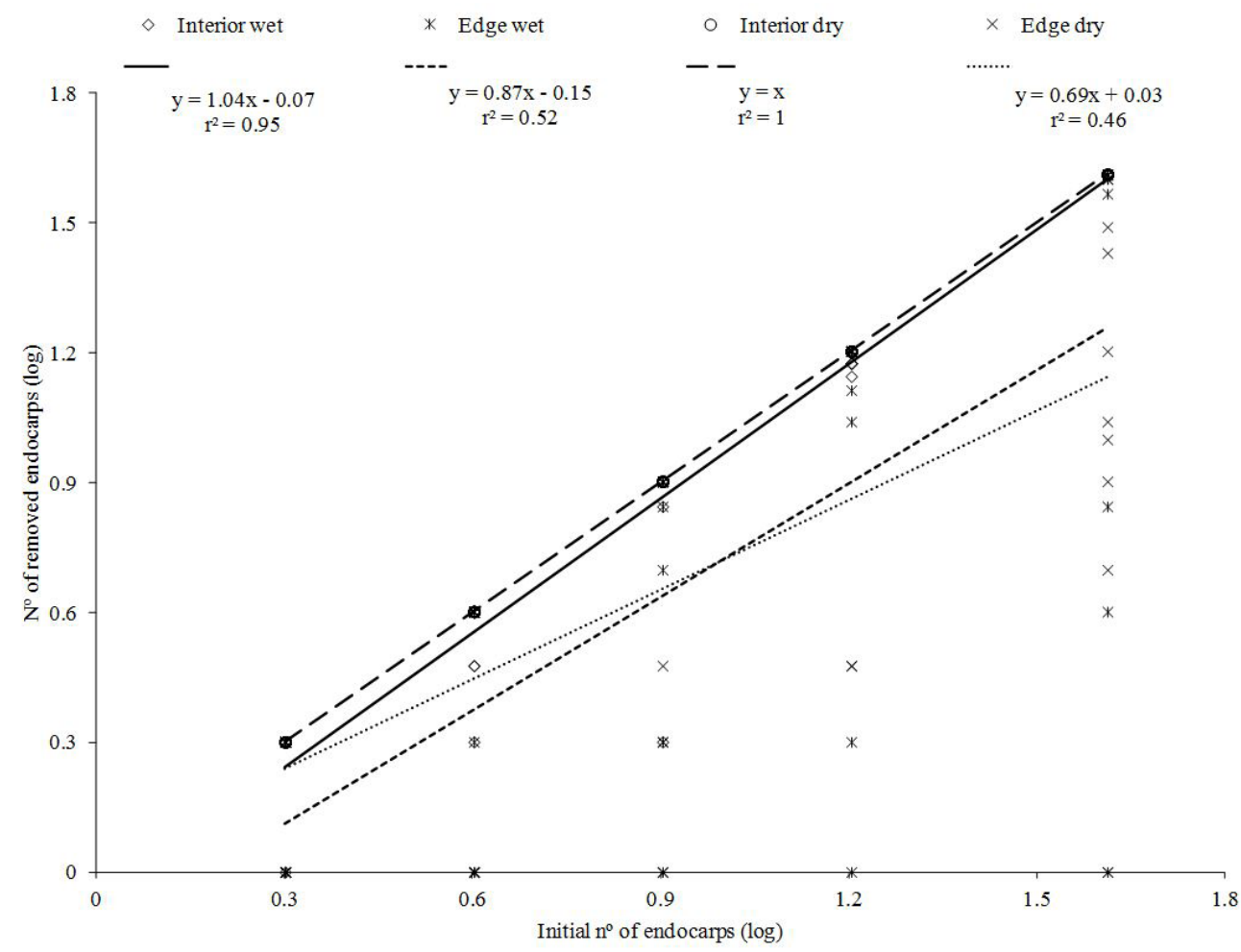

Figure 1. The relationship between the initial and removed number of Dipteryx alata endocarps across habitat types and seasons in the Brazilian Cerrado (Park Natural Municipal do Pombo, Três Lagoas, MS, Brazil. Symbols and linear regressions of log transformed values are also provided).

Table 1. Proportion of depots with complete endocarp removal, proportion of endocarps removed from the total in each endocarp density, as well as, average number $( \pm \mathrm{se})$ of endocarps removed per depot $(\mathrm{n}=9$ for each depot density). This experiment was performed in the Brazilian Cerrado (Pombo Natural Municipal Park, Três Lagoas, State of Mato Grosso do Sul), during the dry and wet season 2014.

\begin{tabular}{|c|c|c|c|c|}
\hline \multicolumn{5}{|c|}{ Season } \\
\hline \multicolumn{2}{|r|}{ Dry } & \multicolumn{3}{|c|}{ Wet } \\
\hline $\begin{array}{c}\mathbf{N}^{0} \text { endocarps } \\
\text { depot }\end{array}$ & $\begin{array}{c}\text { Edge } \\
\text { (proportions: depots; } \\
\text { total of endocarps; } \\
\text { mean } \pm \text { se) } \\
\end{array}$ & $\begin{array}{c}\text { Interior } \\
\text { (proportions: depots; } \\
\text { total of endocarps; } \\
\text { mean } \pm \text { se) } \\
\end{array}$ & $\begin{array}{c}\text { Edge } \\
\text { (proportions: depots; } \\
\text { total of endocarps; } \\
\text { mean } \pm \text { se) } \\
\end{array}$ & $\begin{array}{c}\text { Interior } \\
\text { (proportions: depots; } \\
\text { total of endocarps; } \\
\text { mean } \pm \text { se) }\end{array}$ \\
\hline \multirow{2}{*}{1} & $0.67 ; 0.67$ & $1.00 ; 1.00$ & $0.55 ; 0.55$ & $0.89 ; 0.89$ \\
\hline & $0.67 \pm 0.17$ & $1.00 \pm 0.00$ & $0.55 \pm 0.18$ & $0.89 \pm 0.11$ \\
\hline \multirow{2}{*}{3} & $0.78 ; 0.78$ & $1.00 ; 1.00$ & $0.33 ; 0.37$ & $0.67 ; 0.85$ \\
\hline & $2.33 \pm 0.44$ & $3.00 \pm 0.00$ & $1.11 \pm 0.48$ & $2.55 \pm 0.24$ \\
\hline \multirow{2}{*}{7} & $0.55 ; 0.60$ & $1.00 ; 1.00$ & $0.55 ; 0.73$ & $0.78 ; 0.88$ \\
\hline & $4.22 \pm 1.11$ & $7.00 \pm 0.00$ & $5.11 \pm 0.93$ & $6.22 \pm 0.66$ \\
\hline \multirow{2}{*}{15} & $0.78 ; 0.81$ & $1.00 ; 1.00$ & $0.55 ; 0.73$ & $0.55 ; 0.96$ \\
\hline & $12.11 \pm 1.91$ & $15.00 \pm 0.00$ & $10.89 \pm 2.05$ & $14.44 \pm 0.24$ \\
\hline \multirow{2}{*}{40} & $0.11 ; 0.39$ & $1.00 ; 1.00$ & $0.33 ; 0.67$ & $1.00 ; 1.00$ \\
\hline & $15.67 \pm 4.47$ & $40.00 \pm 0.00$ & $27.00 \pm 6.03$ & $40.00 \pm 0.00$ \\
\hline
\end{tabular}



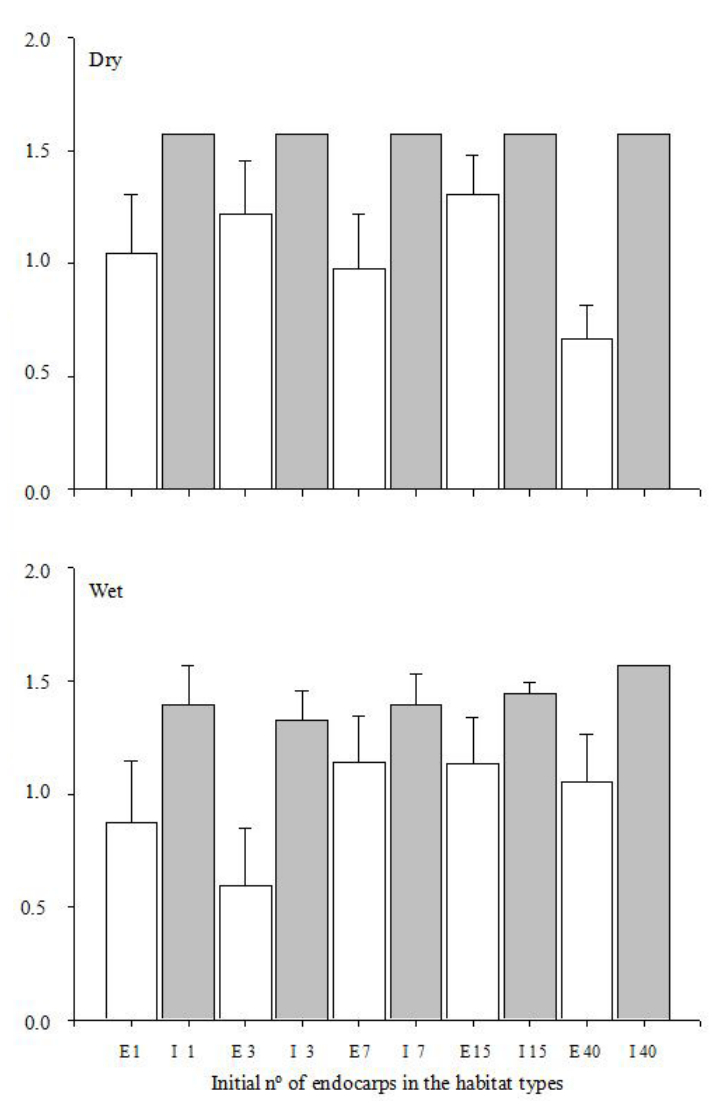

Figure 2. Mean ( $\pm \mathrm{se}$ ) removal proportions of Dipteryx alata endocarps in relation to the size of endocarp depot, season, and habitat type (E: edge, I: interior), in the Brazilian Cerrado (Pombo Natural Municipal Park, Três Lagoas, MS, Brazil).

26 endocarps depredated $(2.9 \pm 1.3)$. On the other hand, in the interior during the dry season, only one depot of $40 \mathrm{had}$ no depredated endocarp. Then, a total of 52 endocarps had seeds eaten $(5.8 \pm 1.6)$, while in the rains four depots exhibited a total of 22 depredated endocarps $(2.4 \pm 1.1)$. Higher numbers of endocarps were depredated in the interior than in the edge (Two-way NPANOVA: $\mathrm{F}=4.85$, $\mathrm{p}=0.035)$. However, in both seasons the number of depredated endocarps was similar $(F=0.10, p=0.775)$. Even then, there was a strong interaction between the two main factors (season and habitat type, $\mathrm{F}=6.68, \mathrm{p}=0.013$ ). Only few other depredated endocarps were present in the edge during rains. One depot of 7 had three depredated endocarps, and two depots of 15 had each one only one depredated endocarp.

\section{Discussion}

Studies have found positive relationships between local seed density and the probability of seed detection by rodents (Hulme, 1994), although, opposite results have also been documented (Hulme and Hunt, 1999). In the present study, in both seasons and habitat types, either piles with few or 40 endocarps were equally likely to be discovered by removers. The absence of any effect attributable to endocarp number on depot detection suggests that removers, over the course of seasons, thoroughly search the Cerrado floor for seeds (Terborgh et al., 1993). Despite of that, habitat type was related to the intensity of endocarp removal, which was smaller in the edge than in the interior of Cerrado. In the anthropized edge a large amount of endocarps remained accumulated without signs of rodent (putative removers) manipulation. In fact, the intensity of seed removal by rodents may be negative density-dependent (this study: edge; Romo et al., 2004), unrelated to density (Hulme and Hunt, 1999), and positive density-dependent (Romo et al., 2004; this study, interior: rains). The use of available seeds by rodents is influenced by factors such as foraging behavior, home range, territoriality, microhabitat preference, predator or competitor avoidance, and the availability of other resources (e.g., Hulme, 1994; Hammond et al., 1999; Hulme and Hunt, 1999). Hence, the response of rodents to a gradient of seed density may be unclear (Hammond et al., 1999). Then, until now high spatio-temporal variability of rodent responses to local seed number may be expected. In the present study, the low removal intensity in the Cerrado edge had as consequence an enhanced accumulation of endocarps, and respective high levels of seed mortality.

The low removal rates of endocarps in the largest depots present in the edge habitat strongly influenced the results in the regression analyses. In both seasons a negative density-dependent response emerged in this site. On the other hand, in the Cerrado interior always depots of 40 lost all endocarps. These contrasting results reinforces that, besides the probability of discovery, the degree of exploitation need to be taken into account to understand seed removal patterns (Romo et al., 2004). If a seed pile is discovered by predators, it might incur in variable rates of removal according to predator species and its local density, besides the availability of alternative food resources (Terborgh et al., 1993; Klinger and Rejmánek, 2009). I documented the lowest intensity of endocarp removal in the edge during the late dry season, a well known period of flesh fruit scarcity in tropical areas (Van Schaik et al., 1993). However, in this period dry fruits might be plentiful in this kind of dense Cerrado (Ragusa-Netto, 2006). Then, when general fruit fall was intense, D. alata endocarps may face intense competition for consumers/dispersers, although this also might be the case for the interior habitat. Perhaps, and most importantly, in the Cerrado edge the lowest removal rates could be consequence of reduced density of large rodents. These mammals are likely to spend much of their time in areas of exceptionally dense understory vegetation where they are safer than in more open habitats (Emmons, 1982). The Cerrado edge was a more open place that, presumably, was avoided by these seed predators, mainly during the late dry season, when bushes and trees were in intense leaf loss (J. Ragusa-Netto, pers. obs.; Ragusa-Netto and Silva, 2007). Moreover, in the edge the low density of rodents might be caused by an 
increase in the density of rodents predator's (Burkey, 1993). In the interior, by their turn, large rodents, in principle, were always common and intensely removed endocarps. Worth of note, remains of depredated endocarps were substantially left in the interior, mainly during the dry season, when no endocarp escaped from rodent manipulation. Then, and at least, the large rodents related to the depredation of those endocarps were very rare in the Cerrado edge. Indeed, vegetation edges usually hold simplified vertebrate fauna where medium and large rodents are poorly represented (Chiarello, 1999; Wright et al., 2007).

Multiple factors may influence whether predator satiation takes place in a particular system, year and site. Often, rodents may be swamped when and where food is plentiful relative to their densities (Vander Wall, 2002; Jansen et al., 2014). The accumulation of $D$. alata endocarps in the Cerrado edge figured as sign of satiation due to the potential low density of large rodents. Reductions in the number of these mammals following fragmentation usually enhance invertebrate predation on the accumulated seeds, mainly by bruchine beetles (Galetti et al., 2006; Mendes et al., 2015). Despite of no attack by insects, D. alata seeds died, mostly in large depots, due to positive density-dependent fungus infestation. Then, in comparison with the Cerrado interior, in both seasons only a reduced number of safe seeds might be present in the edge.

The local extinction of seed vectors negatively affect plants that rely on few frugivore species for dispersal (Cramer et al., 2007). Particularly, large-seeded trees dependent on scatter-hoarding rodents for their regeneration often decline in areas in which this mutualism collapses due to the absence of those seed vectors (Asquith et al., 1997; Jorge and Howe, 2009; Jansen et al., 2012). My results indicate that $D$. alata endocarps exhibit enhanced potential to escape from removal in the Cerrado edge. Indeed, a previous study on D. alata seed fate developed in other three Cerrado remnants pointed out pronounced differences between the interior and edge, mainly in the dry season, when most endocarps suffered no removal in the edges, while $46 \%$ of them were scatter-hoarded in the interior (Wolf, 2015). In principle, in the focused Cerrado edges a disruption in the interactions between scatter-hoarding rodents and $D$. alata is in course, which might ultimately reduce $D$. alata regeneration. It is well known that Dipteryx species strongly rely for their dispersal on caviomorph rodents such as agouties and acouchies (Terborgh and Wright, 1994), which, by handling endocarps, favor seed germination and/or escape from seed pathogens and/or predators (Jansen et al., 2010). Taking into account the loss of scatter-hoarding rodents in fragmented areas (Chiarello, 1999; Cramer et al., 2007), further studies should to compare the spatial distribution of seedlings between the interior and edge of Cerrado to better understand the consequences of reduced seed dispersal on edge populations.

Recent studies have investigated how fragmentation affects plant populations due to the collapse of seed dispersal process (Cordeiro and Howe, 2003; Galetti et al., 2006; Jorge and Howe, 2009). In this study, I evaluated the secondary removal of seeds under the influence of edge creation. The low number of endocarps removed in the Cerrado edge reinforces previous studies in which seed accumulation after primary dispersal could be a sign of defaunation (Cordeiro and Howe, 2001; Galetti et al., 2006). As the present study was developed in one large Cerrado remnant, the results presented here should be acknowledged as preliminary. Studies including a gradient of Cerrado remnant sizes could help to understand if the present results actually represent a pattern or if reductions in $D$. alata endocarps removal are even more severe in smaller fragments from where scatter-hoarding rodents were extirpated (Chiarello, 1999; Galetti et al., 2006; Stoner et al., 2007). With increasing habitat fragmentation, only small rodents may be present in the edges to perform processes such as seed predation (Pinto et al., 2009). Those rodents do not seem to be able to accomplish the roles played by larger mammalian seed predators/dispersers (Burkey, 1993; Cramer et al., 2007; Aliyu et al., 2014). Under these circumstances the progressive accumulation of many large-seeded species (less palatable or inaccessible to small rodents) in the vegetation edge may increase their mortality levels due to pathogens and insect attack (Benítez-Malvido and Lemus-Albor, 2005; Mendes et al., 2015).

Anthropogenic disturbances that reduce and simplify vertebrate communities lead to modifications in seedling recruitment, bringing profound implications for the maintenance of tree community structure (Stoner et al., 2007). As caviomorph rodents promote successful dispersal in Dipteryx species, the scarcity of these vectors might reduce recruitment chances of D. alata in Cerrado remnants. This imply in future changes in the vegetation structure from the edge to the interior towards low tree diversity. This may be of concern as the complex interactions involving primary dispersion of large-seeded trees, their secondary dispersers and seed predators is a key step for devising strategies to conserve ecological processes, which are essential for maintaining biodiversity in fragmented landscapes (Silva and Tabarelli, 2000; Cramer et al., 2007; Costa et al., 2012). This is one few studies comparing the secondary removal of bat dispersed seeds in anthropized habitats of Cerrado (see: Ragusa-Netto and Santos, 2015; Wolf, 2015), one of the most endangered biomes in the world. Due to the accelerated Cerrado loss, knowledge concerning regeneration sources in disturbed Cerrado areas may provide useful information to improve strategies for Cerrado management and conservation in view of the increasing over representation of Cerrado edge habitats (Carvalho et al., 2009).

\section{Acknowledgements}

The author is grateful to an anonymous reviewer for the constructive comments on an earlier version of this study. Flávio Fardim kindly provided logistical support at PMNP. Financial support was provided by Propp/UFMS and CNPq. 


\section{References}

ADLER, G.H., 1998. Impacts of resource abundance on populations of a tropical forest rodent. Ecology, vol. 79, no. 1, pp. 242-254. http://dx.doi.org/10.1890/0012-9658(1998)079[0242:IORAO $\mathrm{P}] 2.0 . \mathrm{CO} ; 2$.

AGUIRRE, L.F., LENS, L., VAN DAME, R. and MATTHYSEN, E., 2003. Consistency and variation in the bat assemblages inhabiting two forest islands within a Neotropical savanna in Bolivia. Journal of Tropical Ecology, vol. 19, no. 04, pp. 367-374. http://dx.doi.org/10.1017/S0266467403003419.

ALIYU, B., ADAMU, H., MOLTCHANOVA, E., FORGET, P.M. and CHAPMAN, H., 2014. The Interplay of habitat and seed type on scatterhoarding behavior in a fragmented afromontane forest landscape. Biotropica, vol. 46, no. 3, pp. 264-267. http://dx.doi. org/10.1111/btp.12110.

ANDERSON, M.J., 2001. A new method for non-parametric multivariate analysis of variance. Austral Ecology, vol. 26, pp. 32-46.

ARTEAGA, L.L., AGUIRRE, L.F. and MOYA, M.I., 2006. Seed rain produced by bats and birds in forest islands in a Neotropical Savanna. Biotropica, vol. 38, no. 6, pp. 718-724. http://dx.doi. org/10.1111/j.1744-7429.2006.00208.x.

ASQUITH, N.M., WRIGHT, S.J. and CLAUSS, M.J., 1997. Does mammal community composition control recruitment in neotropical forests? Evidence from Panama. Ecology, vol. 78, no. 3, pp. 941946. http://dx.doi.org/10.1890/0012-9658(1997)078[0941:DMC $\mathrm{CCR}] 2.0 . \mathrm{CO} ; 2$.

BAGCHI, R., SWINFIELD, T., GALLERY, R.E., LEWIS, O.T., GRIPENBERG, S., NARAYAN, L. and FRECKLETON, R.P., 2010. Testing the Janzen-Connell mechanism: pathogens cause overcompensating density dependence in a tropical tree. Ecology Letters, vol. 13, no. 10, pp. 1262-1269. PMid:20718845. http:// dx.doi.org/10.1111/j.1461-0248.2010.01520.x.

BAROT, S. and GIGNOUX, J., 2004. Mechanisms promoting plant coexistence: can all the proposed processes be reconciled? Oikos, vol. 106, no. 1, pp. 185-192. http://dx.doi.org/10.1111/j.00301299.2004.13038.x.

BENÍTEZ-MALVIDO, J. and LEMUS-ALBOR, A., 2005. The seedling community of tropical rain forest edges and its interaction with herbivores and pathogens1. Biotropica, vol. 37, no. 2, pp. 301-313. http://dx.doi.org/10.1111/j.1744-7429.2005.00031.x.

BOWERS, M.A. and DOOLEY JUNIOR, J.L., 1993. Predation hazard and seed removal by small mammals: microhabitat versus patch scale effects. Oecologia, vol. 94, no. 2, pp. 247-254. http:// dx.doi.org/10.1007/BF00341324.

BURKEY, T.V., 1993. Edge effects in seed and egg predation at two neotropical rainforest sites. Biological Conservation, vol. 66, no. 2, pp. 139-143. http://dx.doi.org/10.1016/0006-3207(93)90145-Q.

CARVALHO, F.M.V., DEMARCO, P.J. and FERREIRA, L.G., 2009. The Cerrado into-pieces: habitat fragmentation as a function of landscape use in the savannas of Central Brazil. Biological Conservation, vol. 142, no. 7, pp. 1392-1403. http://dx.doi. org/10.1016/j.biocon.2009.01.031.

CHAUVET, S. and FORGET, P.M., 2005. Edge effects on postdispersal seed removal in a fragmented rain forest in French Guiana. Journal of Tropical Ecology, vol. 21, no. 01, pp. 113-116. http://dx.doi.org/10.1017/S0266467404001944.
CHIARELLO, A.G., 1999. Effects of fragmentation of the Atlantic forest on mammal communities in south-eastern Brazil. Biological Conservation, vol. 89, no. 1, pp. 71-82. http://dx.doi.org/10.1016/ S0006-3207(98)00130-X.

CONNELL, J.H., 1971. On the role of natural enemies in preventing competitive exclusion in some marine animals and in rain forest trees. In: P.J. DEN BOER, D. GRADWELL, eds. Dynamics of populations. Wageningen: Centre for Agricultural Publishing and Documentation. pp. 298-310.

CORDEIRO, N.J. and HOWE, H.F., 2001. Low recruitment of trees dispersed by animals on African forest fragments. Conservation Biology, vol. 15, no. 6, pp. 1733-1741. http://dx.doi. org/10.1046/j.1523-1739.2001.99579.x.

CORDEIRO, N.J. and HOWE, H.F., 2003. Forest fragmentation severs mutualism between seed dispersers and an endemic African tree. Proceedings of the National Academy of Sciences of the United States of America, vol. 100, no. 24, pp. 14052-14056. PMid:14614145. http://dx.doi.org/10.1073/pnas.2331023100.

COSTA, J.B., MELO, F.P., SANTOS, B.A. and TABARELLI, M., 2012. Reduced availability of large seeds constrains Atlantic forest regeneration. Acta Oecologica, vol. 39, pp. 61-66. http:// dx.doi.org/10.1016/j.actao.2011.12.002.

CRAMER, J.M., MESQUITA, R.C. and WILLIAMSON, G.B., 2007. Forest fragmentation differentially affects seed dispersal of large and small-seeded tropical trees. Biological Conservation, vol. 137 , no. 3, pp. 415-423. http://dx.doi.org/10.1016/j. biocon.2007.02.019.

DONOSO, D.S., GREZ, A.A. and SIMONETTI, J.A., 2004. Effects of forest fragmentation on the granivory of differently sized seeds. Biological Conservation, vol. 115, no. 1, pp. 63-70. http://dx.doi.org/10.1016/S0006-3207(03)00094-6.

EMMONS, L.H., 1982. Ecology of Proechimys (Rodentia, Echimydae) in southeastern Peru. Tropical Ecology, vol. 23, pp. 280-290.

FLEURY, M. and GALETTI, M., 2006. Forest fragment size and microhabitat effects on palm seed predation. Biological Conservation, vol. 131, no. 1, pp. 1-13. http://dx.doi.org/10.1016/j. biocon.2005.10.049.

FORGET, P.M., MILLERONT, F.F., HENRY, O. and DUBOST, G., 2000. Effects of dispersal pattern and mammalian herbivores on seedling recruitment for Virola michelii (Myristicaceae) in French Guiana. Biotropica, vol. 32, no. 3, pp. 452-462. http:// dx.doi.org/10.1111/j.1744-7429.2000.tb00492.x.

FOX, B.J., TAYLOR, J.E., FOX, M.D. and WILLIAMS, C., 1997. Vegetation changes across edges of rainforest remnants. Biological Conservation, vol. 82, no. 1, pp. 1-13. http://dx.doi. org/10.1016/S0006-3207(97)00011-6.

GALETTI, M., DONATTI, C.I., PIRES, A.S., GUIMARÃES, P.R. and JORDANO, P., 2006. Seed survival and dispersal of an endemic Atlantic forest palm: The combined effects of defaunation and fragmentation. Botanical Journal of the Linnean Society, vol. 151 , no. 1 , pp. 141-149. http://dx.doi.org/10.1111/j.10958339.2006.00529.x.

GIVNISH, T.J., 1999. On the causes of gradients in tropical tree diversity. Journal of Ecology, vol. 87, no. 2, pp. 193-210. http:// dx.doi.org/10.1046/j.1365-2745.1999.00333.x.

GOOSEM, M., 2000. Effects of tropical rainforest roads on small mammals: edge changes in community composition. Wildlife 
Research, vol. 27, no. 2, pp. 151-163. http://dx.doi.org/10.1071/ WR98091.

HAMMOND, D.S. and BROWN, V.K., 1995. Seed size of woody plants in relation to disturbance, dispersal, soil type in wet neotropical forests. Ecology, vol. 76, no. 8, pp. 2544-2561. http://dx.doi.org/10.2307/2265827.

HAMMOND, D.S., BROWN, V. and ZAGT, R., 1999. Spatial and temporal patterns of seed attack and germination in a largeseeded neotropical tree species. Oecologia, vol. 119, no. 2, pp. 208-218. http://dx.doi.org/10.1007/s004420050778.

HANSON, T., BRUNSFELD, S. and FINEGAN, B., 2006. Variation in seedling density and seed predation indicators for the emergent tree Dipteryx panamensis in continuous and fragmented rain forest. Biotropica, vol. 38, no. 6, pp. 770-774. http://dx.doi. org/10.1111/j.1744-7429.2006.00204.x.

HARMS, K.E., WRIGHT, J.W., CALDERON, O., HERNANDEZ, A. and HERRE, E.A., 2000. Pervasive density dependent recruitment enhances seedling diversity in tropical forest. Nature, vol. 404, no. 6777, pp. 493-495. PMid:10761916. http://dx.doi. org/10.1038/35006630.

HOLL, K.D. and LULOW, M.E., 1997. Effectsof species, habitat, and distance from edge on post-dispersal seed predation in a tropical rainforest. Biotropica, vol. 29, no. 4, pp. 459-468. http:// dx.doi.org/10.1111/j.1744-7429.1997.tb00040.x.

HOWE, H.F. and SMALLWOOD, J., 1982. Ecology of seed dispersal. Annual Review of Ecology and Systematics, vol. 13, no. 1, pp. 201-228. http://dx.doi.org/10.1146/annurev.es.13.110182.001221.

HULME, P.E., 1994. Post-dispersal seed predation in grassland: its magnitude and sources of variation. Journal of Ecology, vol. 82, no. 3, pp. 645-652. http://dx.doi.org/10.2307/2261271.

HULME, P. and HUNT, M., 1999. Rodent post-dispersal seed predation in deciduous woodland: predator response to absolute and relative abundance of prey. Journal of Annimal Ecology, vol. 68 , pp. 417-428.

JANSEN, P.A., ELSCHOT, K., VERKERK, P.J. and WRIGHT, S.J., 2010. Seed predation and defleshing in the agouti-dispersed palm Astrocaryum standleyanum. Journal of Tropical Ecology, vol. 26, no. 05, pp. 473-480. http://dx.doi.org/10.1017/S0266467410000337.

JANSEN, P.A., HIRSCH, B.T., EMSENS, W.J., ZAMORAGUTIERREZ, V., WIKELSKI, M. and KAYS, R., 2012. Thieving rodents as substitute dispersers of megafaunal seeds. Proceedings of the National Academy of Sciences of the United States of America, vol. 109, no. 31, pp. 12610-12615. PMid:22802644. http://dx.doi.org/10.1073/pnas.1205184109.

JANSEN, P.A., VISSER, M.D., WRIGHT, J.S., RUTTEN, G. and MULLER-LANDAU, H.C., 2014. Negative density dependence of seed dispersal and seedling recruitment in a Neotropical palm. Ecology Letters, vol. 17, no. 9, pp. 1111-1120. PMid:25039608. http://dx.doi.org/10.1111/ele.12317.

JANZEN, D.H., 1970. Herbivores and the number of tree species in tropical forests. American Naturalist, vol. 104, no. 940, pp. 501-527. http://dx.doi.org/10.1086/282687.

JORGE, M.L.S.P. and HOWE, H.F., 2009. Can forest fragmentation disrupt a conditional mutualism? A case from central Amazon. Oecologia, vol. 161, no. 4, pp. 709-718. PMid:19633870. http:// dx.doi.org/10.1007/s00442-009-1417-7.

KLINGER, R. and REJMÁNEK, M., 2009. The numerical and functional responses of a granivorous rodent and the fate of
Neotropical tree seeds. Ecology, vol. 90, no. 6, pp. 1549-1563. PMid:19569370. http://dx.doi.org/10.1890/07-2146.1.

LORENZI, H., 1994. Árvores Brasileiras: manual de identificação e cultivo de plantas arbóreas nativas do Brasil. Nova Odessa: Editora Plantarum. vol. 1, 384 p.

MELO, F.P.L., DIRZO, R. and TABARELLI, M., 2006. Biased seed rain in forest edges: evidence from the Brazilian Atlantic forest. Biological Conservation, vol. 132, no. 1, pp. 50-60. http:// dx.doi.org/10.1016/j.biocon.2006.03.015.

MELO, F.P.L., RODRIGUEZ-HERRERA, B., CHAZDON, R.L., MEDELLIN, R.A. and CEBALLOS, G.G., 2009. Small tent-roosting bats promote dispersal of large-seeded plants in a Neotropical forest. Biotropica, vol. 41, no. 6, pp. 737-743. http:// dx.doi.org/10.1111/j.1744-7429.2009.00528.x.

MENDES, C.P., RIBEIRO, M.C. and GALETTI, M., 2015. Patch size, shape and edge distance influence seed predation on a palm species in the Atlantic forest. Ecography, vol. 38, pp. 1-11.

MONTIEL, S., ESTRADA, A. and LÉO, P.M., 2006. Bat assemblages in a naturally fragmented ecosystem in the Yucatan Peninsula, Mexico: species richness, diversity and spatio-temporal dynamics. Journal of Tropical Ecology, vol. 22, no. 03, pp. 267-276. http:// dx.doi.org/10.1017/S026646740500307X.

MURCIA, C., 1995. Edge effects in fragmented forests: Implications for conservation. Trends in Ecology \& Evolution, vol. 10, no. 2, pp. 58-62. PMid:21236953. http://dx.doi.org/10.1016/S01695347(00)88977-6.

PINTO, S.R.R., SANTOS, A.M. and TABARELLI, M., 2009. Seed predation by rodents and safe sites for large-seeded trees in a fragment of the Brazilian Atlantic forest. Brazilian Journal of Biology = Revista Brasileira de Biologia, vol. 69, no. 3, pp. 763-771. PMid:19802435. http://dx.doi.org/10.1590/S151969842009000400003

RAGUSA-NETTO, J., 2006. Dry fruits and the abundance of the Blue-and-Yellow Macaw (Ara ararauna) at a cerrado remnant in central Brazil. Ornitologia Neotropical, vol. 17, pp. 491-500.

RAGUSA-NETTO, J. and SANTOS, A.A., 2015. Seed rain generated by bats under Cerrado's pasture remnant trees in a Neotropical savanna. Brazilian Journal of Biology $=$ Revista Brasileira de Biologia, vol. 75, no. 4, suppl. 1, pp. 1-10. PMid:26602344. http:// dx.doi.org/10.1590/1519-6984.22813.

RAGUSA-NETTO, J. and SILVA, R.R., 2007. Canopy phenology of a dry forest in western Brazil. Brazilian Journal of Biology $=$ Revista Brasileira de Biologia, vol. 67, no. 3, pp. 569-575. PMid:18094842. http://dx.doi.org/10.1590/S1519-69842007000300024.

RIBEIRO, J.F. and WALTER, B.M.T., 1998. Fitofisionomias do cerrado. In: S.M. SANO and S.P. ALMEIDA, eds. Cerrado: ambiente e flora. Planaltina: EMBRAPA. pp. 89-166.

ROMO, M., TUOMISTO, H. and LOISELLE, B.A., 2004. On the density-dependence of seed predation in Dipteryx micrantha, a bat-dispersed rain forest tree. Oecologia, vol. 140, no. 1, pp. 76-85. PMid:15148597. http://dx.doi.org/10.1007/s00442-004-1502-x.

SAUNDERS, D.A., HOBBS, R.J. and MARGULES, C.R., 1991. Biological consequences of ecosystem fragmentation: a review. Conservation Biology, vol. 5, no. 1, pp. 18-32. http://dx.doi. org/10.1111/j.1523-1739.1991.tb00384.x.

SCHUPP, E.W., 1988. Seed and early seedling predation in the forest understory and in tree fall gaps. Oikos, vol. 51, no. 1, pp. 71-78. http://dx.doi.org/10.2307/3565808. 
SCHUPP, E.W., 1992. The Janzen-Connell model for tropical tree diversity: population implications and the importance of spatial scale. American Naturalist, vol. 140, no. 3, pp. 526-530. PMid:19426055. http://dx.doi.org/10.1086/285426.

SCHUPP, E.W. and FUENTES, M., 1995. Spatial patterns of seed dispersal and the unification of plant population ecology. Ecoscience, vol. 2, no. 3, pp. 267-275. http://dx.doi.org/10.108 0/11956860.1995.11682293.

SILMAN, M.R., TERBORGH, J.W. and KILTIE, R.A., 2003. Population regulation of a dominant rain forest tree by a major seed predator. Ecology, vol. 84, no. 2, pp. 431-438. http://dx.doi. org/10.1890/0012-9658(2003)084[0431:PROADR]2.0.CO;2.

SILVA, J.M. and TABARELLI, M., 2000. Tree species impoverishment and the future flora of the Atlantic forest of northeast Brazil. Nature, vol. 404, no. 6773, pp. 72-73. PMid:10716443. http:// dx.doi.org/10.1038/35003563.

STONER, K.E., VULINEC, K., WRIGHT, S.J. and PERES, C.A., 2007. Hunting and plant community dynamics in tropical forests: a synthesis and future directions. Biotropica, vol. 39, no. 3, pp. 385-392. http://dx.doi.org/10.1111/j.1744-7429.2007.00291.x.

TERBORGH, J., LOSOS, E., RILEY, M.P. and BOLAÑOS RILEY, M., 1993. Predation by vertebrates and invertebrates on the seeds of five canopy tree species of an Amazonian forest. Vegetatio, vol. 107/108, pp. 375-386.

TERBORGH, J. and WRIGHT, S.J., 1994. Effects of mammalian herbivores on plant recruitment in two neotropical forests. Ecology, vol. 75, no. 6, pp. 1829-1833. http://dx.doi.org/10.2307/1939641.
TERBORGH, J., 2012. Enemies maintain hyperdiverse tropical forests. American Naturalist, vol. 179, no. 3, pp. 303-314. PMid:22322219. http://dx.doi.org/10.1086/664183.

VAN SCHAIK, C.P., TERBORGH, J.W. and WRIGHT, S.J., 1993. The phenology of tropical forests, adaptive significance, and consequences for primary consumers. Annual Review of Ecology and Systematics, vol. 24, no. 1, pp. 353-377. http:// dx.doi.org/10.1146/annurev.es.24.110193.002033.

VANDER WALL, S.B., 2002. Masting in animal-dispersed pines facilitates seed dispersal. Ecology, vol. 83, no. 12, pp. 35083516. http://dx.doi.org/10.1890/0012-9658(2002)083[3508:MI ADPF]2.0.CO;2.

WENNY, D.G., 2000. Seed dispersal, seed predation, and seedling recruitment of a neotropical montane tree. Ecological Monographs, vol. 70, no. 2, pp. 331-351. http://dx.doi.org/10.1890/00129615(2000)070[0331:SDSPAS]2.0.CO;2.

WILLIAMS-LINERA, G., 1990. Origin and early development of forest edge vegetation in Panama. Biotropica, vol. 22, no. 3, pp. 235-241. http://dx.doi.org/10.2307/2388533.

WOLF, M., 2015. Roedores como agentes secundários na remoção de endocarpos de "baru" (Dipterix alata Vogel) em borda e interior de fragmentos de Cerrado. Campo Grande: Universidade Federal de Mato Grosso do Sul, 32 p. Dissertação de Mestrado em Biologia Animal.

WRIGHT, S.J., HERNANDÉZ, A. and CONDIT, R., 2007. The bushmeat harvest alters seedling banks by favoring lianas, large seeds, and seeds dispersed by bats, birds, and wind. Biotropica, vol. 39, no. 3, pp. 363-371. http://dx.doi.org/10.1111/j.17447429.2007.00289.x. 